\title{
IRENE GIL E SOFIA POMBA GUERRA: VOZES DE MULHERES PORTUGUESAS EM MOÇAMBIQUE NAS PÁGINAS DE ITINERÁRIO
}

\section{Resumo}

Neste artigo, pretende-se abordar a questão da participação feminina na revista moçambicana Itinerário (1941-1955), nomeadamente na década de 1940, antes do processo das independências africanas. Entre as várias contribuições, escolheu-se analisar parte da produção de duas mulheres portuguesas, pertencentes à classe média, radicadas em Moçambique, Irene Gil e Maria Sofia Pomba Guerra, podendo estas ser interpretadas como exemplos paradigmáticos de dois olhares contrastantes sobre a missão da mulher na sociedade colonial.

Palavras-chaves: Revista Itinerário, Moçambique, Irene Gil, Sofia Pomba Guerra.

\begin{abstract}
Irene Gil and Sofia Pomba Guerra: voices of Portuguese women in Mozambique from the pages of Itinerário

This article aims to discuss the female participation in the Mozambican magazine Itinerário (1941-1955), specifically in the 1940s, before the process of African independences. Among the different contributions, I decided to analyse part of the works of two middle-class Portuguese women living in Mozambique, Irene Gil and Maria Sofia Pomba Guerra, who perfectly embody two opposing concepts of the mission of women in the colonial society.
\end{abstract}

Keywords: Magazine Itinerário, Mozambique, Irene Gil, Sofia Pomba Guerra.

\section{Resumen}

Irene Gil y Sofia Pomba Guerra: voces de mujeres portuguesas in Mozambique en las páginas de Itinerário

Este artículo aborda la cuestión de la participación femenina en la revista mozambiqueña Itinerário (1941-1955), principalmente en la década de 1940, antes del proceso de las independencias africanas. Entre las diferentes contribuciones, he decido analizar parte de la producción de dos mujeres portuguesas, pertenecientes a la clase media, radicadas en Mozambique, Irene Gil y Maria Sofia Pomba Guerra, ejemplos paradigmáticos de dos miradas contrastantes sobre la misión de la mujer en la sociedad colonial.

Palabras clave: revista Itinerário, Mozambique, Irene Gil, Sofia Pomba Guerra.

Dipartimento di Lingue e Letterature Straniere, Università degli Studi di Milano, 20123 Milano, Itália.

Endereço postal: Università degli Studi di Milano, Dipartimento di Lingue e Letterature Straniere, Piazza Sant'Alessandro, 1, 20123 Milano MI, Itália

Endereço eletrónico: ada.milani@mail.com; ada.milani@unimi.it

ORCID: https: / / orcid.org/0000-0001-5311-4595 


\section{Introdução}

Fruto da iniciativa de um grupo de colonos, a revista Itinerário: publicação mensal de letras, arte, ciência e crítica começa a sua trajetória no mês de fevereiro de 1941 na então Lourenço Marques. ${ }^{1}$ Apesar da predominância de vozes masculinas, nota-se, a partir dos primeiros números, uma considerável atenção à esfera feminina, seja com a publicação de artigos que refletem sobre a condição da mulher de uma perspetiva exterior (a questão da modernização moral, social e intelectual das mulheres, o problema do desemprego e da prostituição, etc.), seja através de contribuições diretas onde as mulheres intervêm em assuntos considerados especialmente femininos (a puericultura, a educação dos filhos, entre outros) ou em questões sociais e políticas que envolvem toda a coletividade. Muitos são os artigos que discutem as mudanças imprimidas, a nível global, pelas guerras mundiais, nomeadamente na perceção que as mulheres tinham de si mesmas e do seu valor não só como humildes «fadas do lar». Entre as colaboradoras de Itinerário, sobressaem duas figuras, a escritora Irene Gil e a farmacêutica Sofia Pomba Guerra, portadoras de visões contrastantes que contribuem para a leitura da sociedade da época através de olhares divergentes. Tomando em consideração os artigos de opinião (e excluindo, portanto, os de caráter literário), irá tentar-se desvendar as visões das duas autoras no que diz respeito à sociedade moçambicana da década de 1940, ao papel da mulher na sociedade colonial, aos seus deveres enquanto fornecedora de mão-de-obra complementar à masculina na «ingente tarefa de desbravar terras incultas e de as transformar em zonas de cultura» (Guerra 1949a, 3) ou ainda, com especial referência aos meios urbanos, ao valor exemplar da mulher branca ${ }^{2}$ na «civilização» de mainatos e de trabalhadoras indígenas.

\section{Missão familiar e missão colonial da mulher portuguesa}

A primeira voz feminina a manifestar-se na primeira pessoa, logo na primeira página do n. ${ }^{\circ} 16$ de 1942, é a da poetisa e escritora Irene Gil. No artigo «O que nós

1 O surgimento de Itinerário ocorreu numa fase precedente ao auge da migração portuguesa para Angola e Moçambique. Os fundadores são brancos da classe média culta e com habilitações profissionais; é lícito, aliás, estabelecer uma ligação entre alguns dos fundadores-colaboradores e os meios anarcossindicalistas, a partir do primeiro diretor, Alexandre Sobral de Campos (veja-se A. Thomas Lane, Biographical Dictionary of European Labor Leaders, 911-912).

2 Relativamente a Angola e Moçambique, a categoria «população branca» é utilizada nas estatísticas da época para designar os naturais da Europa, ou os seus descendentes de pele clara, residentes nas duas colónias, independentemente do local de nascimento. Em Moçambique, destaca-se a presença de outros brancos, além dos naturais da Metrópole: os britânicos ocupavam o primeiro lugar entre os estrangeiros e, ao contrário do que acontecia em Angola, residiam em Moçambique comunidades de indianos e de chineses, tanto de origem portuguesa como britânica (Castelo 2007, 215-217). 
queremos» - respondendo ao pedido de colaboração publicado no número de comemoração do primeiro aniversário do jornal -, Irene Gil pega em papel e caneta para fazer ouvir a própria voz enquanto mulher portuguesa radicada em Moçambique:

Itinerário é o jornal da gente nova. Que a gente nova a ele venha dizer o que pensa, sente e quer, é o voto que faço na entrada deste ano novo. - Estas palavras, escritas por um brilhante colaborador do Itinerário [...] fizeram-me pensar que, no concerto de vozes que hão de elevar-se, que é preciso que se elevem no conjunto harmónico que há de orientar a sociedade futura, é justo que tome parte uma voz feminina - uma voz obscura de mulher portuguesa (Gil 1942a, 1).

O artigo traz uma reflexão sobre a dificuldade de secundar de maneira acrítica os incessantes apelos à maternidade, especialmente em tempos de guerra. Embora concordando com os que acreditam ser a salvaguarda da proliferação o principal tributo que as mulheres podem oferecer à sociedade, a escritora convida a não considerar a diminuição da natalidade apenas como indicador de frivolidade e, relativamente à escolha de ter ou não ter filhos, refere a documentada incidência negativa das mortes e das devastações causadas pela guerra. Irene Gil ergue-se para exigir que os esforços das mulheres não sejam frustrados pelos «senhores da guerra»:

A religião, a moral, a própria política, a cada passo nos lembram o dever de contribuirmos para alicerçar [...] as bases duma sociedade melhor, mais forte, mais feliz e mais numerosa. [...] É do conhecido médico e escritor Alexis Carrel esta ideia [...] «uma mulher, fisicamente apta para a maternidade, será uma criatura menos forte, menos feliz, menos útil, se se recusar a cumprir esta sua função essencial». [...] Mas, em troca da nossa boa vontade, do nosso sacrifício, da compreensão das necessidades da hora presente que todas as vozes autorizadas nos impõem - nós, mulheres de todo o mundo, também temos direito a reclamar das forças organizadas ou ainda obscuras que hão-de reger, amanhã, o destino dos povos, esta promessa capital:

- Que se organize uma sociedade onde haja justiça, equidade, respeito pelas vidas que nos aconselham gerar. [...] Que se nos peça, sim, o cumprimento das leis divinas e naturais para que tende o nosso instinto feminino e maternal - mas não para que, daqui a outros vinte anos, quando os nossos filhos forem o nosso orgulho e a nossa razão de viver - no-los matem em nome doutra qualquer Nova Ordem que mascara, afinal, o velho espírito de cobiça e de opressão que desde sempre atira os povos uns contra outros (Gil 1942a, 1).

Depois deste primeiro artigo, Irene Gil estabelecerá com a redação do jornal uma intensa colaboração que irá tocar nas principais problemáticas sociais da época. No mês de julho de 1942, Itinerário publica outro escrito da autora. «Femini- 
lidade e feminismo» aborda primeiramente o tema do feminismo, assunto que «apaixona as mulheres cultas e as intelectuais de todo o mundo» (Gil 1942b, 5) apesar de ser «quase sempre encarado com um sorriso de troça irreverente por todos os que apenas vêem na mulher uma fútil boneca de luxo e de prazer» (Gil 1942b, 5). Embora admitindo que o movimento feminista tenha tido excessos condenáveis, como de resto qualquer aspiração manifestada depois de uma «repressão dolorosa e longa» (Gil 1942b, 5), Irene Gil volta a examinar o empenho das mulheres durante as guerras mundiais, onde elas se afirmaram não só no âmbito artístico, como também no campo de batalha, mostrando a própria força física e emotiva:

Foi uma guerra sangrenta - a de 1914-1918 - que, completando o movimento já esboçado no último quartel do século XIX, por assim dizer «forçadamente» revelou ao homem as possibilidades de inteligência e de trabalho da sua companheira que, salvo raríssimas excepções - permanecera até ali apagada e obscura. E, tal como na outra guerra, todos sabemos que, durante esta, não é só na cátedra, no professorado, nas artes que a mulher afirma as suas capacidades de espírito: mas guiando caminhões e ambulâncias, conduzindo eléctricos, trabalhando nas fábricas de material de guerra, cooperando enfim, com o homem em serviços pesados, pouco compatíveis com a sua suposta e aparente fragilidade (Gil 1942b, 5).

Já com o olhar virado para o futuro, Irene Gil pergunta-se qual poderá ser, depois do "período anormal e violento da guerra», a reação da mulher perante os hábitos de emancipação e liberdade adquiridos; a resposta é bem sintetizada na seguinte metáfora: «Por mim, penso que será a mesma que obriga um pêndulo, violentamente sacudido por circunstâncias exteriores, a retomar, depois de oscilações mais ou menos fortes, o equilíbrio natural» (Gil 1942b, 5). A proposta de Irene Gil é, portanto, a de um feminismo em ponta de pés, um compromisso entre o passado e os «desvios» provocados pela guerra, de maneira que a mulher possa recuperar o seu equilíbrio natural no papel de esposa, mãe, educadora, enfim a sua função de «tesoureira do futuro»:

Entre essa doce, mas antiquada figura do passado [...] e a mulher ultra-emancipada e andrógina que quer talhar, sozinha, o seu caminho na vida, masculinizada e infeliz, deve existir um meio termo [...] o da mulher [...] culta sem pedantismo, graciosa sem exagero, amorosa sem pieguice, pronta a fazer ao marido o prato que ele prefere, mas pronta também a compreendê-lo e a auxiliá-lo nas suas investigações científicas [...] nas suas realizações artísticas (Gil 1942b, 5).

Estão aqui resumidos os requisitos da mulher do pós-guerra, que, segundo a escritora, já não precisa de ocultar as próprias capacidades, mas deve estar consciente do próprio lugar e dos limites que deve impor a si mesma para não correr o risco de invadir o espaço masculino. 
Um dos âmbitos onde mais afloram as possibilidades da mútua cooperação entre homens e mulheres é o da política colonial, que revela uma nova missão da mulher. Relativamente à distribuição por sexos da população europeia de Moçambique, sabe-se, graças às pesquisas de Cláudia Castelo, que entre a década de 1920 e a de 1940 reduziu-se notavelmente a desproporção entre o número de homens e de mulheres, acabando por se aproximar da paridade:

em 1928, havia 11618 homens e apenas 6224 mulheres (53,6 mulheres em cada 100 homens); em 1935 os homens eram 13903 e as mulheres 9228 (66,4 mulheres em cada 100 homens); em 1940 foram apurados 16032 homens e 11406 mulheres (71,1 mulheres em cada 100 homens); em 1950, a população branca de residência habitual era formada por 27917 homens e 20296 mulheres (73 mulheres em cada 100 homens); em 1955, apuraram-se 36662 homens e 29136 mulheres ( 79 mulheres em cada 100 homens); e, finalmente, em 1960, residiam na província 53685 homens brancos e 43560 mulheres brancas, o que significava que para 100 brancos havia 81,1 brancas (Castelo 2007, 231-232).

Ainda que a emigração ultramarina atinja o clímax só no segundo pós-guerra, já no início dos anos 1940 sucedem-se debates sobre a necessidade de uma maior intervenção do Estado nas questões ligadas ao povoamento, tal como mostra o artigo «Colonização», publicado no n. ${ }^{\circ} 20$ de Itinerário, em 1942:

Um dos pontos essenciais da nossa colonização é a emigração. Esta é a consequência dum fenómeno económico-social, que se não pode contrariar nem violentar, mas pelo contrário, regular. Se Portugal é um país que - como muitos outros - só por si não tem recursos suficientes para poder dar trabalho a todos os que ali nascem e vivem, evidentemente que deve facultar e canalizar as correntes emigratórias para as suas colónias, onde existem vastos recursos naturais, riquezas do solo, do sub-solo, fauna, etc. (Bentes 1942, 1).

Além de pedir em voz alta o auxílio do governo com o objetivo de melhorar a situação agrícola e as condições sociossanitárias dos colonos, o autor coloca, significativamente, entre os seus «preceitos» o encorajamento da viagem ultramarina das esposas e dos filhos dos colonos:

Fixe o Governo os planaltos e as zonas mais saudáveis das colónias [...] para estabelecimento do colono; dê-lhe passagem para si e família; [...] estimule no metropolitano a atracção pela vida das colónias e a confiança no próprio Estado [...] e, dentro de algumas dezenas de anos, teremos desvendado todos os mistérios da selva africana, convertendo-a em enormes plantações, em lindos pomares, em lindas cidades, vilas e aldeias que serão a continuação de Portugal (Bentes 1942, 1).

A imprescindível contribuição das mulheres portuguesas para que se cumpra o «milagre da colonização» é um conceito reafirmado com maior firmeza na página 
três do mesmo número, onde aparecem os artigos «A mulher moçambicana», assinado por Mário Soares, e «A nossa missão», escrito por Irene Gil. O primeiro dos dois artigos, depois de distinguir a mulher moçambicana entre europeia e indígena, analisa o problema capital da «mulher portuguesa branca» (Soares 1942, 3) em matéria de política colonial insistindo nos «deveres supremos e sagrados» que, para além da maternidade, cabem à mulher para contribuir para o conjunto construtivo da Colónia:

Casada, ela deve acompanhar o marido para os lugares onde ele exercer a sua profissão ou onde se fixar. E não acompanhar simplesmente, em sentimento, como suavizadora da sua vida de trabalho. [...] deve ser preparada para poder tomar parte e colaborar [...] na vida, por exemplo, da agricultura e da indústria, a que se dediquem o marido e o pai - a mulher pode e deve ser preparada para os ramos da medicina e da higiene, do professorado e das obras de assistência social (Soares 1942, 3).

A certeza de que a mulher possa ser na colónia «admirável elemento de eficaz cooperação», é reiterada no artigo de Irene Gil, que forma um todo com o precedente, tentando ambos resgatar as mulheres da posição subalterna. $\mathrm{O}$ texto abre-se com uma reflexão sobre os deveres que incumbem às novas gerações de «mulheres coloniais» (Gil 1942c, 3) e levam a missão feminina acima das «obrigações primordiais» - «cuidar do lar, criar e educar os filhos, ser boa dona de casa, boa esposa, boa mãe»; estes novos deveres podem ser resumidos num «programa modesto, mas fecundo [...]: colaborar, com o homem, na grande obra de civilização que é o destino secular da nossa raça - predestinada, adaptável, colonizadora como nenhuma outra» (Gil 1942c, 3). Eis exposto o «fardo da mulher branca» (Burton 1990, 295-308), que a autora sintetiza num panorama que vai desde as primeiras explorações até ao império luso-brasileiro, num estilo que reflete os clichés da retórica colonial (a predestinação do povo lusitano; a língua, companheira do império; a dilatação da fé; a capacidade de adaptação lusotropicalista):

Desde há muito que a mulher portuguesa, com a percepção nítida desse destino, acompanha o homem em viagens aventurosas pelas cinco partes do mundo.

Desbravadas as rotas dos oceanos, dominados os terrores e as lenda do «Mar Tenebroso» pela mão hercúlea dos nossos capitães, logo, a caminho da Índia, como, mais tarde a caminho do Brasil - seguiram «donas dos tempos idos», ajudando a fundar, nessa terra que foi berço das nossas maiores glórias, famílias e tradições que perduraram através de tantos séculos e vicissitudes, sem que por um só momento se apagasse na sua lâmpada o azeite votivo do culto pela Pátria, do apego à língua, do amor à religião tradicional dos seus maiores (Gil 1942c, 3).

Aos tempos idos de glória, sobrepõe-se, na perspetiva de Irene Gil, o tempo presente da fixação nas colónias africanas, onde as mulheres, desempenhando 
uma profissão ou acompanhando pais e maridos, poderão finalmente encontrar a própria missão nas «pródigas terras do ultramar». A missão enquanto educadora, por exemplo, não limitada à esfera familiar, mas alargada às empregadas domésticas indígenas:

eu penso que esses milhares de mulheres, de fremente entusiasmo e generoso coração, nalguma coisa poderão contribuir para que se realize [...] a nossa maravilhosa missão de portugueses e de colonizadores.

- Como? Incutindo e cultivando, não só no coração dos seus filhos, mas também no dos seus servos, o amor de Portugal.

Contando-lhes os nossos feitos de antanho, desvendando ante o seu espírito virgem e maravilhado a história das viagens que há 500 anos trouxeram até às suas terras estes brancos que eles respeitam e estimam - na medida em que, por nosso lado, os estimarmos e respeitarmos como seres embrionários ou talvez decadentes, mas, como nós, portadores da ideia de justiça, da noção nítida do Bem e do Mal.

Ensinando-lhes com paciência a nossa língua, desvendando-lhes os mistérios do alfabeto - porque eu não creio, como muitos, que de nada vale ao preto saber ler [...].

Enfim [...] chamando a nós a rapariga indígena, utilizando-a, de preferência ao homem, como serva, para que vá aprendendo connosco as elementares noções de asseio, de higiene e até de puericultura que esteja em nossa mão ministrar-lhe.

Sem desejar de parecer excessivamente optimista, creio no entanto que uma vez casada, essa rapariga levaria para o seu lar alguma coisa do que aprendesse connosco. Apesar da tradicional preguiça da raça nem tudo se perderia.

Se a tivéssemos ensinado a costurar ela coseria, decerto, a sua blusa, a sua capulana e teria vergonha de aparecer descuidada diante do aprumo das outras. [...] E pouco a pouco esses nossos costumes, no seu lado mais prático e utilizável, iriam entrando no lar indígena pela mão dessas raparigas às quais pacientemente ensináramos o seu ofício de mulheres (Gil 1942c, 3).

De particular interesse é o retrato que emerge dos indígenas, a meio caminho entre povos infantis e povos decaídos ou decadentes - imagens onde ecoam as posições ora positivas ora depreciativas de pensadores do século XVIII (cf. Scwarcz e Gomes 2018, 421) -, possibilitados de sair da sua condição de «seres embrionários» (Gil 1942c, 3) graças à política da assimilação. Evidentemente, a reflexão de Irene Gil é marcada pela retórica paternalista da missão civilizadora e pela lógica da superioridade cultural europeia, contudo, ao mesmo tempo que sustenta a legitimidade dos preconceitos raciais (a inata indolência e despreocupação dos pretos), a escritora revela uma sincera atenção aos problemas higiénicos e de desnutrição ${ }^{3}$ :

A atenção ao relacionamento com «os indígenas», por um lado, e a persistência de ideias ligadas à retórica paternalista da missão civilizadora e à «invenção do nativo», por outro, encontram-se também na fase sucessiva da produção jornalística de Irene Gil (veja-se Falconi 2014). 
Caberia ao Estado a organização duma obra mais vasta e mais eficaz enviando periodicamente [...] enfermeiras competentes e especializadas às terras do interior [...] prestar assistência às mães indígenas [...] e ministrar-lhes um curso elementar de puericultura e higiene.

Desapareceriam assim [...] os ventres dilatados, as tremendas hérnias umbilicais que envergonham a raça, e de que sofrem talvez, pelo menos no norte da Colónia, 30 a 40\% das crianças africanas.

Mas enquanto isso se não consegue [...] poderíamos nós [...] empenhar-nos nessa tarefa bem humana, bem cristã, bem feminina - contribuindo assim para que o nível de existência da indígena se eleve lentamente da simples condição de fêmea dominada pelo atavismo, pela ignorância e pelo instinto - à posição mais cristã e mais dignificante de mulher (Gil 1942c, 3).

A mulher branca é chamada a desenvolver, nas colónias africanas, a função de garante do progresso social e de agente da civilização. No discurso de Irene Gil, o olhar feminista funde-se com o commandement colonial (Mbembe 2005) e participa da assunção da superioridade - nacional, racial, religiosa - implícita na cultura portuguesa dominante naquela época, levando a um tipo de «imperialismo maternal» num processo semelhante ao descrito por A. M. Burton:

o feminismo, tal como o imperialismo, estruturou-se à volta da ideia de responsabilidade moral. [...] O feminismo e a ideologia da reforma feminina ditaram praticamente a existência de clientelas dependentes a quem conferir apoio, conforto e (expectavelmente) o estatuto de terem sido salvos. No contexto imperial, a tutela trazia a promessa da redenção moral; o que, de acordo com a forma como foi concebido pelas feministas, estava dependente do sexo feminino na sua capacidade de ser redentor. [...] Nem um sentido de missão podia estar divorciado do entusiasmo evangélico cristão subjacente à corrente dominante do feminismo. [...] a mulher era uma metáfora para o progresso social e a civilização. O melhor método para levar a cabo estes objetivos era serem as mulheres a atender às necessidades umas das outras, uma vez que apenas as mulheres podem conhecer as verdadeiras necessidades das mulheres (Burton 1990, 296-300).

\section{Sofia Pomba Guerra e a resistência às 'formas inibitórias de pensamento'}

Entre 1945 e 1949, nomeadamente por ocasião das eleições para a Assembleia Nacional e da sucessiva candidatura de Norton de Matos à presidência da República ${ }^{4}$, a revista Itinerário torna pública a sua própria linha ideológica, manifestando «um claro [...] posicionamento anti-ditadura, publicando-se ocasionalmente

4 Sobre a campanha de Norton de Matos, o «segundo ciclo da resistência antifascista» e as ligações com o PCP, veja-se Rosas (2010) e Mateus e Mateus (1999). 
alusões à falta de liberdade de expressão, reunião e propaganda» (Rosário 1996, 115). O movimento de revolta em relação ao regime, desencadeado em Portugal no clima de euforia pela vitória dos Aliados, tem um impacto significativo nos meios moçambicanos da oposição, cujas atividades clandestinas - promovidas por alguns membros do «grupo da Itinerário» - podem ser lidas como reflexo das ações do MUD, do MUD-Juvenil e do PCP. Neste período, para além de publicar artigos de crítica ao salazarismo e à política colonial, a revista funciona, de facto, como "centro de irradiação de atividade política clandestina» (Mendonça 2012, 205) e como «elo de ligação entre os intelectuais e os oposicionistas do regime» (Mateus 2006, 443), graças à atuação de alguns colaboradores reunidos num grupo progressista de intelectuais antifascistas. Dentro deste grupo, Sofia Pomba Guerra tem um papel relevante, protagonizando um engajamento concreto na luta contra o regime colonial-fascista.

Farmacêutica, analista e professora alentejana, muda-se cedo para o Ultramar, onde se distingue pelas atividades comunistas, antifascistas e anticolonialistas (cf. Esteves 2013, 705). Em 1946, entrega às colunas da Itinerário os artigos «A mulher francesa» e «A natalidade e o problema da infância em França», relativos à condição feminina na França do pós-guerra. A primeira «crónica de Paris» é dedicada àquelas «pioneiras da resistência» que combateram pela liberdade:

Nas prisões, nas câmaras de tortura, combatendo nas organizações clandestinas e nas barricadas, sofrendo com firmeza e lutando com coragem, a mulher francesa alcançou a sua maioridade pelo direito de conquista, depois de lhe ter sido largamente negada pelo direito de justiça. [...] Centenas de mulheres [...] foram presas pela polícia de Pétain, para as entregar ao inimigo. Esses homens, que tinham posto nos seus cartazes grandes letreiros de nacionalismo e defesa da família, é que [...] metiam, com as mães, em enxovias sem ar, sem alimentação quase, sem higiene, crianças pequenas a ponto de à data de libertação haver crianças com cinco anos de idade e três de prisão (Guerra 1946a, 1).

Sofia Pomba Guerra evidencia como a emancipação feminina passou também através da ação política e, considerando a vigorosa oposição ao regime que marcará toda a vida desta mulher, é significativa a crítica aos supostos «defensores da família» e a referência à associação feminina afim ao Partido Comunista, nascida na clandestinidade.

A segunda crónica aborda o tema da crise da natalidade em França, problema já mencionado num dos artigos de Irene Gil, mas aqui desenvolvido minuciosamente por meio de referências pontuais aos estudos de Maria Rabaté, política francesa membro do PCF:

É de todos sabido que a França tem sido um país de população decrescente e que isso representa uma auto-condenação nacional. [...] Não basta que as crianças nasçam, é 
preciso «conservar-lhes a vida», é preciso não atemorizar as jovens mães com um luto cruel que as atinja no primeiro filho. Esse temor é justificado, pois se a percentagem da natalidade aumentou, a percentagem da mortalidade infantil aumentou também 75\% sobre a percentagem de 1939. Maria Rabaté visita as Maternidades, aponta as suas deficiências, a má situação e portanto fraco rendimento, do pessoal que as serve. Poucas Maternidades em relação ao número dos nascimentos: insuficiente número de camas; enfermarias sobrecarregadas; insuficiência de ambulâncias para transporte e de roupas; alimentação mal equilibrada às parturientes (Guerra 1946b, 1).

A mesma atenção aos dados estatísticos encontra-se nos artigos sobre a situação da colónia. Um dos primeiros textos votados à sociedade moçambicana intitula-se «A alimentação e a capacidade intelectual dos indígenas» e, em contraponto com o último artigo referido de Irene Gil, pode ser lido como uma tentativa de combater um dos mais comuns preconceitos racistas contra as populações indígenas:

Instintiva e naturalmente, quase sem precisar de raciocínio prévio, o habitante branco de Moçambique tem como verdade evidente que o preto é inapto para chegar onde chega o branco, no que diz respeito a trabalho, quer manual quer intelectual (Guerra 1947, 16).

Contrariando a imagem do negro indolente ou escassamente desenvolvido do ponto de vista intelectual, Pomba Guerra declara que os «factores de potencialidade rácicas» (Guerra 1947,16) não são determinantes para estabelecer o grau de civilização de um povo e que a "pigmentação da pele já hoje não pode ser tomada a sério como exprimindo qualquer relação de capacidade ou incapacidade intelectual» (Guerra 1947, 16). A autora admite, porém, que «o negro de Moçambique não ultrapassou ainda um nível muito baixo de cultura» e aponta como causas as insuficiências alimentares: «Se excluirmos uma muitíssimo pequena minoria, que poderá constituir exceção, mas não a lei geral, a população negra alimenta-se mal, a um nível inferior ao considerado humano» (Guerra 1947, 16). Baseando as suas argumentações em estudos sobre deficiências alimentares conduzidos em França durante a Segunda Guerra Mundial, Pomba Guerra conclui que:

Se compararmos as privações alimentares da juventude francesa durante a guerra com a natureza da alimentação do indígena moçambicano em qualidade e em tempo; se analisarmos o perigo que os higienistas franceses atribuem ao seu caso nacional, como abaixamento do nível intelectual dum povo, não nos espantará, por certo, que o negro de Moçambique seja indolente, sem vivacidade intelectual e não tenha podido elevar-se como capacidade de cultura.

Temos a considerar que não é apenas uma geração a [ser] atingida, mas centenas de gerações deficientes, incapazes, transmitindo sem cessar esta incapacidade. As possibi- 
lidades do preto, como raça, só poderão avaliar-se se previamente se submeter, durante algumas gerações, a uma alimentação suficiente e equilibrada (Guerra 1947, 16).

Em 1948, Pomba Guerra publica «O trabalho da mulher», artigo que começa com um longo discurso sobre o valor do trabalho no progresso material de uma sociedade - «sem trabalho não há produção» (Guerra 1948, 1) - e sobre a valorização do indivíduo, de maneira que ao incremento quantitativo corresponda uma maior apreciação qualitativa dos homens e das mulheres, principais fatores de produção:

O exemplo que o homem é o capital mais precioso temo-lo aqui à porta no chamado «problema da mão de obra». Há terras agricultáveis, ricos minérios aproveitáveis, quedas de água, carvão [...] tudo isso, porém, pode permanecer abandonado ao lado do homem miserável, andrajoso e faminto, se o trabalho humano não vier transformar essas riquezas potenciais [...] em objectos de consumo. [...] Mas devemos ter em conta que a possibilidade quantitativa de produzir riqueza depende ainda da qualidade do trabalho. Quanto mais valorizado estiver o indivíduo pelo treino e cultura [...] tanto maiores valores poderá produzir na unidade de tempo [...]. A aptidão humana, a possibilidade de auto-valorização, [...] são determinantes decisivos na prosperidade e progresso dum território (Guerra 1948, 1).

Esta explicação serve como pressuposto para introduzir uma reflexão sobre o trabalho feminino, sublinhando a necessidade de uma adequada valorização das mulheres. Mais uma vez, o parâmetro é a Segunda Guerra Mundial, ao longo da qual as mulheres se distinguiram como protagonistas essenciais:

Vem isto a propósito de certas «opiniões» ultimamente publicadas na imprensa, que parecem ignorar a prova feita [...] durante as duas Grande Guerras, do valor precioso e factor imprescindível que a mulher representa na produção. Afirmar o contrário representaria apenas inconsciência análoga à de quem se resolvesse agora a ser de opinião, por exemplo, que não existem micróbios, porque nunca os viu [...]. Temos de convir que a ignorância de factos não é argumento suficientemente convincente para conduzir a qualquer prova. Pelo contrário, ficou nitidamente provado que o trabalho da mulher não só é útil, mas imprescindível no esforço necessário à violência duma guerra moderna e à reconstrução das destruições causadas por essa guerra (Guerra 1948, 1).

Na segunda metade do artigo, Pomba Guerra concentra-se na situação moçambicana, fornecendo exemplos práticos de como as mulheres - aproveitando as possibilidades do ambiente (nem sempre favorável) - estão a encaminhar-se para a plena valorização: 
Tudo isto indica [...] que a mulher em Moçambique não promete menores aptidões do que as suas irmãs dos países assolados pela guerra [...]. A mulher em Moçambique, dentro das possibilidades de trabalho que se lhe oferecem e que não são, na maioria dos casos, positivamente ideais para desenvolver vocações, está a dar boa conta de si (Guerra 1948, 3).

Índice do novo caminho são os resultados dos concursos para os serviços públicos, que atestam os esforços das mulheres, a sua dedicação ao estudo e ao trabalho:

Aos concursos para operadores dos C.T.T. apresentaram-se 20 homens e 20 mulheres, sendo aprovados 15 homens e 17 mulheres, das quais estas em $1 .^{\circ}, 2^{\circ}{ }^{\circ}, 4 .^{\circ}$ e 5 . lugar, ficando em 3. ${ }^{\circ}$ lugar um homem. Nos concursos para terceiros oficiais dos Serviços de Instrução, as mulheres ficaram classificadas em $1 .^{\circ}, 2{ }^{\circ}, 3 .^{\circ}$ e $4 .^{\circ}$ lugar, vindo um homem em 5. lugar (Guerra 1948, 3).

Levando a sua análise para lá dos limites da perspetiva de género, a autora utiliza estes dados irrefutáveis como base para uma observação mais ampla:

Factos destes [...] deviam agradar a todos os que compreendem ser a valorização humana um dos mais importantes factores económicos de progresso, tanto mais estarmos num país com tantas riquezas em potencial inexploradas, que só aguardam o esforço fecundo do trabalho. Pois parece haver ainda gente convencida que refrear actividades, estiolar possibilidades conduz à felicidade humana. Em Moçambique território com mais de 770000 quilómetros quadrados, contendo no seu solo preciosas riquezas, a maior parte delas possivelmente ignoradas, com uma população nativa de 5 milhões de almas, de diminuta valorização cultural e técnica, apenas com 55000 habitantes não indígenas - advogar a restrição da actividade dos seus habitantes com o fim de evitar a concorrência é dar a maior prova de incapacidade a ter o direito de emitir opiniões. [...] num país com tanta riqueza inexplorada, tal princípio pode mesmo ter-se como altamente pernicioso ao seu progresso, espécie de fetichismo anacrónico, prejudicial, que conduz à asfixia económica e serve de obstáculo a todas as finalidades construtivas (Guerra 1948, 3).

Começa aqui a despontar a crítica à política do Estado Novo, que nas páginas da Itinerário atingirá o ápice em 1949, no período da chamada «liberdade suficiente» (Soares 1974, 97). No n. ${ }^{\circ}$ 85, Sofia Pomba Guerra publica «O Estado Novo não defende os interesses das classes médias e das camadas populares» $(1949 a, 3)$ artigo em que desnuda a realidade puramente ilusória do regime português, incapaz de trazer qualquer benefício ao progresso da nação (cf. Milani 2019, 14):

O que decide [...] na apreciação serena das atitudes dos governantes, em qualquer período da História, não são as frases pomposas transmitidas pelos seus arautos e 
trombeteiros, mas a aplicação, na prática, das suas afirmações. O que se decide são as obras que se realizam. O que impõe os governantes à admiração dos cidadãos é progresso económico e social e intelectual que as vastas camadas usufruam e não o bem estar de uma minoria [...]. [...] O Estado Novo [...] não pode gabar-se, a não ser por auto-ilusão ou intenção mistificadora, de se impor, por prestígio governativo, aos olhos dos sectores mais importantes da vida nacional. O Estado Novo em 22 anos de existência mostrou, perfeitamente, a sua incapacidade para resolver os problemas centrais do País (Guerra 1949a, 3-6).

Uma prova do desprestígio do regime encontra-se na falta de método e planificação característica da política colonial portuguesa:

Na vida colonial e nesta província ultramarina a política do Estado Novo em relação às classes médias, expressa-se na desesperante situação dos colonos, a quem falta protecção e interesse das autoridades governativas e centrais, quer em ajuda económica, quer em auxilio técnico, quer em formas de actuação que facilitem ou pelo menos apoiem a ingente tarefa de desbravar terras incultas e de as transformar em zonas de cultura. [...] Ouvem-se a cada passo os queixumes [...] dos agricultores e criadores, que lutam desesperadamente para não soçobrarem, ao mesmo tempo que se constata toda a fragilidade de uma colonização feita sem método e sem plano, movida grandemente por interesses que não são os das populações coloniais e dos seus vários sectores laboriosos. Moçambique, sob a orientação do Estado Novo, continuará vivendo à míngua dos recursos próprios, sem uma protecção decisiva ao seu comércio, à sua agricultura e à sua indústria, que não progride, como consequência da linha política directiva em que se baseiam os representantes do corporativismo (Guerra 1949a, 3-6).

A esperança num futuro de paz e democracia é personificada na figura de Norton de Matos, «símbolo da democracia e da pátria» (Guerra 1949b, 3), como titula outro artigo assinado por Sofia Pomba Guerra no número seguinte. O texto concentra-se na questão da política ultramarina do General, passando em revista as obras desenvolvidas em Angola. O que emerge é uma imagem positiva de Norton de Matos, cuja vida colonial representa uma «prova incontestável de bom senso e grandeza civilizadora» (Guerra 1949b, 3), por exemplo, na relação com as povoações indígenas (tendo desincentivado a violência e a exploração e, por outro lado, encorajado a pacífica convivência das raças) ou na assistência material aos colonos:

Desde a primeira hora em que pisou terras de Angola, o general Norton de Matos afirmou o seu propósito de realizar uma obra colonial sem preocupações de partido, alicerçada, sobretudo, em métodos de compreensão pelas massas indígenas atrasadas [...]. Trabalhou sinceramente pela abolição de violência na administração colonial, protegeu o indígena, concedendo-lhe condições para o tornar um proprietário agrícola ou um artífice tecnicamente preparado para as suas funções profissionais e para 
as necessidades da vida nativa e pôde, assim, criar, através de tal acção, um núcleo populacional que deu o primeiro grande impulso à participação do negro na vida económica de Angola sem ser sob a forma de trabalho compelido. Norton de Matos compreendeu que brancos e negros podiam e podem ser colaboradores numa grande obra de aproveitamento da riqueza africana, sem atropelos que comprometem a nossa soberania e afugentam das províncias ultramarinas as populações espezinhadas (Guerra 1949b, 3).

A forte crítica ao Estado Novo e à sua política ultramarina passa então pela exaltação do programa colonial de Norton de Matos, não chegando a questionar abertamente o «direito histórico» (Guerra 1949b, 3) de Portugal sobre os territórios africanos, assunto delicado, até no seio da Oposição (cf. Milani, 2019, 21).

Poucos meses depois de ter assinado estes últimos artigos, em outubro de 1949, Sofia Pomba Guerra foi presa na sequência de uma ação repressiva da PIDE e sucessivamente deportada para a metrópole, juntamente com outros militantes do Movimento dos Jovens Democratas de Moçambique:

eram acusados de dirigir o Movimento, actuando sob orientação da Organização Comunista de Moçambique (que seria uma ramificação do PCP), de aliciarem novos membros sem distinção de cor, raça ou nacionalidade, [...] de elaborarem e distribuírem panfletos clandestinos de doutrinação política [...].

Assim, na madrugada de 17 de Outubro de 1949, sem aviso prévio (com excepção de Sofia Pomba Guerra, a quem foi perguntado a quem queria que entregassem as filhas menores à sua guarda e encargo), os presos são levados, num cortejo de seis veículos motorizados e por ruas fortemente patrulhadas, para o cargueiro Sofala, em que viajam até Lisboa.

Abner Sansão Mutemba, testemunha presencial, declara ser perfeitamente audível uma voz feminina que gritava:

«Chamo-me Sofia Pomba Guerra e vou ser deportada. Viva Moçambique» (Mateus e Mateus 2010, 22-23).

Sofia Pomba Guerra ficou detida em Caxias até ao mês de julho de 1950. Depois de absolvida e libertada, foi obrigada a escolher residência fora do País; partiu então para Cabo Verde, onde se juntou ao marido, empregado como funcionário público, e seguiu depois para a Guiné, onde chegou a assumir um papel de relevo junto do embrionário nacionalismo independentista guineense.

\section{Conclusões}

Com os seus artigos publicados no Itinerário, Irene Gil e Sofia Pomba Guerra oferecem um valioso testemunho da rearticulação do papel da mulher na imprensa colonial durante as décadas de 1930 e 1940. Embora ambas sejam expressão da classe 
média branca, enquanto portuguesas instruídas e radicadas em Moçambique, as suas tomadas de posições refletem dois olhares contrastantes: a primeira, apesar da incontestável atenção para com as e os «indígenas», denuncia ainda uma clara atitude paternalista (cf. Laban 1998, 312); a segunda, pelo contrário, distingue-se no jornalismo e na luta anticolonial, livrando-se do «fardo» da cumplicidade na manutenção da máquina imperial.

\section{Referências bibliográficas}

Bentes, João. 1942. «Colonização». Itinerário 20: 1.

Burton, Antoinette M. 1990. «The white woman's burden: British feminists and the Indian woman, 1865-1915». Women's Studies International Forum 13 (4): 295-308. DOI: https: / / doi.org/10.1016/0277-5395(90)90027-U

Castelo, Cláudia. 2007. Passagens para África: o Povoamento de Angola e Moçambique com Naturais da Metrópole. Porto: Edições Afrontamento.

Esteves, José. 2013. «Maria Sofia Carrejola Pomba do Amaral Guerra». In Feminae - Dicionário Contemporâneo, dirigido por João Esteves e Zília Osório de Castro, 705-707. Lisboa: Comissão para a Cidadania e Igualdade de Género. Disponível em http: / / cid.cig.gov. pt/nyron/Library/Catalog/winlibimg.aspx?skey=509C87A2501541B98F5BB22EED3CB516\&doc $=95065 \&$ img $=139416$

Falconi, Jessica. 2014. «Em torno do silêncio sobre Novas Cartas Portuguesas em Angola e Moçambique». In Novas Cartas Portuguesas: Entre Portugal e o Mundo, organizado por Ana Luísa Amaral e Marinela Freitas, 589-627. Alfragide: Dom Quixote.

Gil, Irene. 1942a. «O que nós queremos». Itinerário 16: 1.

Gil, Irene. 1942b. «Feminilidade e feminismo». Itinerário 18: 5.

Gil, Irene. 1942c. «A nossa missão». Itinerário 20: 3.

Guerra, Maria Sofia Pomba. 1946a. «A mulher francesa». Itinerário 62: 1.

Guerra, Maria Sofia Pomba. 1946b. «A natalidade e o problema da infância em França». Itinerário (63): 1.

Guerra, Maria Sofia Pomba. 1947. «A alimentação e a capacidade intelectual dos indígenas». Itinerário (64-65): 16-17.

Guerra, Maria Sofia Pomba. 1948. «O trabalho da mulher». Itinerário (73): 1-3.

Guerra, Maria Sofia Pomba. 1949a. «O Estado Novo não defende os interesses das classes médias e das camadas populares». Itinerário 85: 3-6.

Guerra, Maria Sofia Pomba. 1949b. «Norton de Matos símbolo da democracia e da pátria». Itinerário 86: 3, 16, 17.

Laban, Michel. 1998. «Entrevista a Noémia de Sousa». In Moçambique: encontro com escritores, vol. III: 278. Porto: Fundação Eng. António de Almeida.

Mateus, Dalila Cabrita. 2006. Memórias do colonialismo e da guerra. Alfragide: ASA.

Mateus, Dalila Cabrita, e Álvaro Mateus. 1999. A luta pela independência. Lisboa: Inquérito.

Mbembe, Achille. 2005. Postcolonialismo. Milano: Meltemi.

Mendonça, Fátima. 2012. «Dos confrontos ideológicos na Imprensa em Moçambique». In Os Outros da Colonização, organizado por Cláudia Castelo et al. Lisboa: Imprensa de Ciências Sociais.

Milani, Ada. 2019. «Mulheres e imprensa periódica colonial: engajamento político e social na revista moçambicana 'Itinerário' ». In De Oriente a Ocidente: estudos da Associação Inter- 
nacional de Lusitanistas, vol. III, organizado por Cláudia Pazos Alonso et al., 7-25 Coimbra: Angelus Novus. Disponível em https:/ / lusitanistasail.press/index.php/ailpress/ catalog/book/165

Rosário, Lourenço do. 1996. «A Literatura Moçambicana e o Escritor Moçambicano - Uma Questão Polémica». In Singularidades. Estudos africanos, 111-116. Lisboa: Edições Universitárias Lusófonas.

Rosas, Fernando. 2010. «Norton de Matos e as eleições presidenciais de 1949. Uma candidatura em contraciclo». In Norton de Matos e as eleições presidenciais de 1949, coordenado por Heloísa Paulo e Helena Pinto Janeiro, 9-16. Lisboa: Colibri.

Scwarcz, Lilia M., e Flávio Gomes, orgs. 2018. Dicionário da escravidão e liberdade. São Paulo: Companhia das Letras.

Soares, Mário. 1942. «A mulher moçambicana». Itinerário 20: 3.

Soares, Mário. 1974. Portugal amordaçado: depoimento sobre os anos do fascismo. Lisboa: Arcádia.

Ada Milani. Professora de Literaturas Africanas de Língua Portuguesa na Universidade de Milão. Mestrado pela Universidade de Milão com uma tese sobre o pensamento anticolonialista de Amílcar Cabral. Doutoramento em Literaturas Modernas e Comparadas pela Universidade de Génova com uma tese sobre a revista moçambicana Itinerário. Os seus interesses de investigação situam-se na área das literaturas africanas em português e, nomeadamente, no papel da imprensa periódica no surgimento da literatura moçambicana na década de 40 e 50.

Endereço eletrónico: ada.milani@unimi.it

Artigo recebido a 7 de janeiro de 2019 e aprovado para publicação dia 10 de abril de 2019. 